\title{
ARTICLE
}

Cite this: DOI: $10.1039 /$ xoxxooooox

Received ooth January 2012,

Accepted ooth January 2012

DOI: 10.1039/xoxxooooox

www.rsc.org/

\section{Organophosphorus-catalyzed Diaza-Wittig reaction: Application to the synthesis of pyridazines}

\author{
Hassen Bel Abed, ${ }^{a}$ Oscar Mammoliti, ${ }^{b}$ Omprakash Bande, ${ }^{a}$ Guy Van Lommen ${ }^{b}$ \\ and Piet Herdewijn ${ }^{* a}$
}

The elaboration of the first organophosphorus-catalyzed Diaza-Wittig reaction is reported. This catalytic reaction is applied to the synthesis of substituted pyridazine and phthalazine derivatives bearing electron-withdrawing groups with good to excellent yields from substrates containing a diazo functionality as starting material and a phospholene oxide as catalyst.

\section{Introduction}

Pyridazine $^{1}$ is an important heterocyclic ring known to be present in ligands targeting different receptors such as GABA, ${ }^{2}$ kinase $^{3}$ or cannabinoid receptors ${ }^{4}$ and in various natural products. Moreover the pyridazine ring has been proposed as "privileged structure" for drug design by Prof. Wermuth." During the last years, different methods have been developed for the synthesis of pyridazines ${ }^{6}$ due to an increasing interest of the pharmaceutical industry for this 1,2-diazine. As part of our ongoing interest ${ }^{7}$ in the elaboration of heterocycles valuable for drug design projects, we have put considerable efforts in the synthesis of novel functionalized pyridazine.
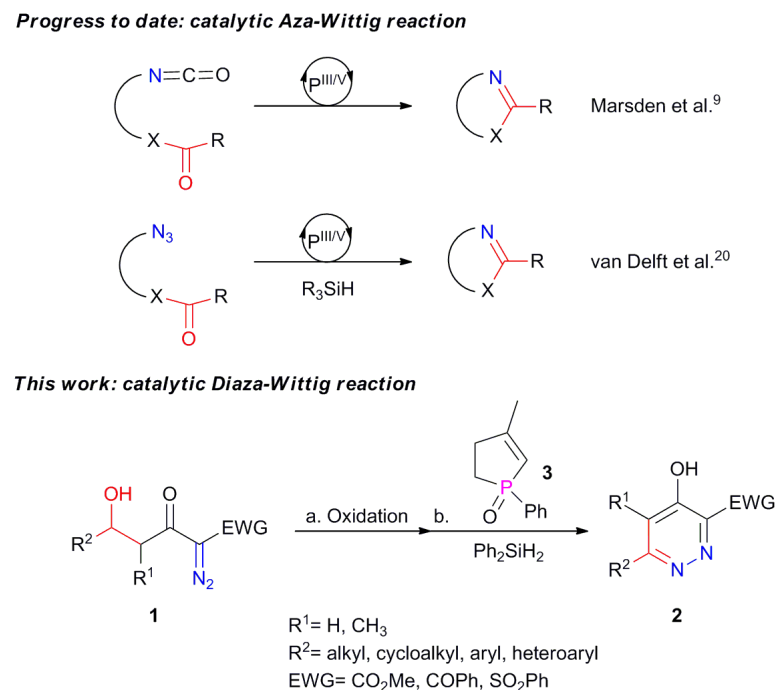

Scheme 1 Organophosphorus-catalyzed synthesis of heterocycles.
We recently developed a protocol for the synthesis of pyridazine analogues $\mathbf{2}$ by intramolecular Diaza-Wittig from diazo derivatives 1 using HMPT as reagent. ${ }^{8}$ In our search for innovative and safe pathways, the elaboration of a catalytic Diaza-Wittig reaction became highly desirable (Scheme 1). The first example of the synthesis of a heterocycle by using a catalytic amount of organophosphorus reagent was reported in 2008 by the pioneering work of the Marsden group. ${ }^{9}$ An isocyanate group was needed to regenerate the phosphine oxide following a mechanism of activation, described by Campbell et al. for the production of carbodiimides. ${ }^{10}$

Several important reactions are mediated by organophosphorus reagents such as Appel reaction, ${ }^{11}$ Mitsunobu reaction ${ }^{12}$ or Wittig olefination, ${ }^{13}$ and numerous groups have been focused on the development of a catalytic approach of these reactions. Two general strategies have been investigated; the redox-neutral process as used by Denton et al. to develop the first example of catalytic phosphorus mediated dichlorination of epoxides under Appel reaction conditions. ${ }^{14}$ The second strategy is the redox-driven mechanism which combines an organophosphorus reagent and a reducer. The O'Brien group ${ }^{15}$ has investigated the reduction of phosphine oxide into the corresponding phosphine by using silane as reducing reagent, in contrast to previously described harsh conditions $^{16}$ not compatible with all substrates. The introduction of a silane as mild reducer can be considered as a remarkable breakthrough in this field. This reduction led to the first catalytic olefination reaction as well as a catalytic Mitsunobu reaction on the phosphine component. The Rutjes group ${ }^{17}$ has dedicated a part of its research to the development of tunable organophosphorus catalysts and their successful application to organophosphorus-catalyzed reaction (Appel reaction, ${ }^{18}$ Staudinger reduction of azide ${ }^{19}$ and sequential Staudinger/Aza-Wittig synthesis of heterocycles ${ }^{20}$ ). It has been 
demonstrated that the choice of the phosphine oxide is critical to achieve the reduction by silane reagent. In fact, van Delft et al. has shown that cyclic phosphine oxide is effectively reduced compared to acyclic phosphine oxide such as triphenyl phosphine oxide. $^{21}$ 5-Membered phospholane gave the best results and directed our work towards the use of the commercially available phospholene oxide $\mathbf{3}$ as catalyst.

\section{Results and discussion}

The development of a catalytic Diaza-Wittig reaction can be divided in a four-step catalytic process. The first step is the reduction of the phospholene oxide $\mathbf{3}$ into the corresponding phospholene $\mathbf{5}$ with a silane reagent $\mathbf{4}$. The second step is the formation of a phosphazine intermediate 7 from the reaction between $\mathbf{5}$ and a diazo derivative $\mathbf{6}$. Then the phosphazine $\mathbf{7}$ is converted into an oxazaphosphetane intermediate $\mathbf{8}$ prior to the last step leading to the desired pyridazine $\mathbf{2}$ and regeneration of the phospholene oxide 3 (Scheme 2).

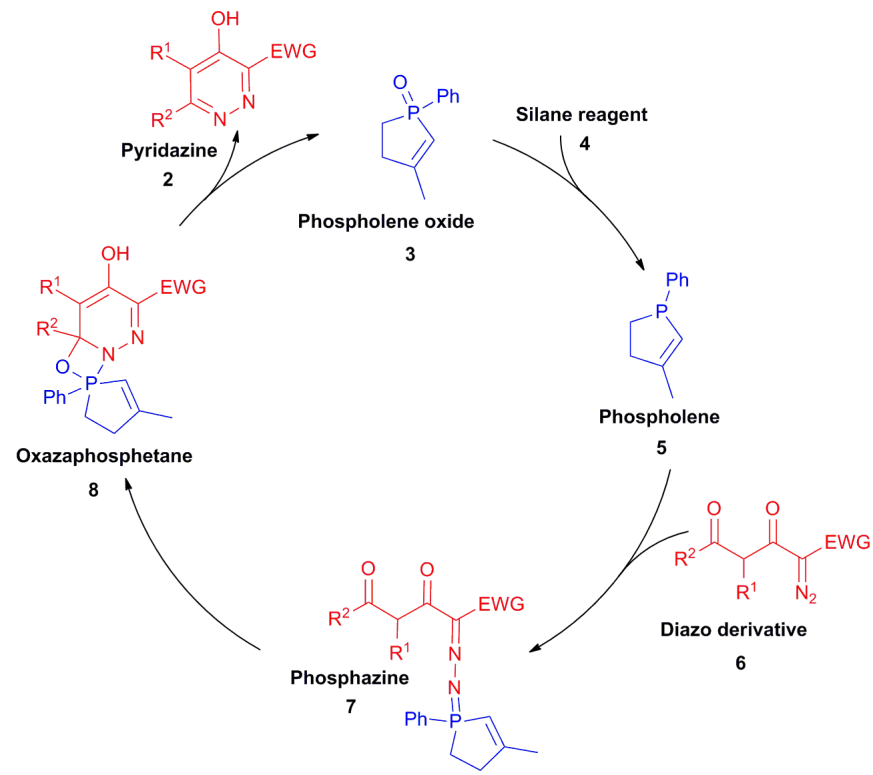

Scheme 2 Proposed catalytic cycle for the Diaza-Wittig reaction.

The reduction of phosphine oxide into the corresponding phosphine with silane reagent has proved to be chemoselective in the presence of aldehyde, ketone and azide functionality but it is the first report of this reduction in the presence of a diazo group to the best of our knowledge. The reduction of the phosphine oxide did not affect the diazo group and the cyclization leading to the pyridazine could be achieved. A study on the effect of the phosphine, silane, solvent, temperature and reaction time has been performed on the conversion of $\mathbf{1 a}$ into 2a. In order to prove that the original reaction with stoichiometric amount of HMPT (Table 1, entry 1) cannot be catalytic, the reaction with 25 mol $\%$ of phosphine was run for 48 hours, never exceeding a yield of $15 \%$ (Table 1, entry 2). A reaction with a stoichiometric amount of HMPA demonstrated that phosphine oxide alone is not enough to obtain the pyridazine (Table 1, entry 3 ). Likewise, using catalytic amount of triphenyl phosphine oxide or HMPA with diphenylsilane led to no formation of pyridazine $\mathbf{2 a}$ (Table 1, entry 4-5). While varying the silane reagent and using a catalytic amount of phospholene oxide $\mathbf{3}$, the use of phenylsilane led to the formation of the desired product $\mathbf{2 a}$ in moderate yield (Table 1, entry 6). By using diphenylsilane, the pyridazine 2 a was obtained in excellent yields and no purification was necessary due to the precipitation of the desired pyridazine after cooling down the reaction (Table 1, entry 14-15). As a control reaction, no formation of pyridazine $\mathbf{2 a}$ was observed in the absence of the silane reagent (Table 1, entry 16).

The temperature seems to be an important parameter. When the reaction was performed in $\mathrm{CH}_{2} \mathrm{Cl}_{2}$ at room temperature, like the reaction with HMPT, 2a was not formed (Table 1, entry 7). An increase of the temperature to $65^{\circ} \mathrm{C}$ with $\mathrm{CH}_{3} \mathrm{CN}$ as solvent did not give better results (Table 1, entry 8). A high temperature $\left(100^{\circ} \mathrm{C}\right)$ was needed to perform the first step of the catalytic process i.e. the reduction of $\mathbf{3}$ by the silane reagent. In $\mathrm{DMF}$ as well as in dioxane at $100{ }^{\circ} \mathrm{C}$, it was possible to obtain 2a in good yield and purification by flash chromatography on silica gel was necessary (Table 1, entry 9-10). Toluene is the only solvent which gives $\mathbf{2 a}$ in excellent yields and without purification. A sealed tube was used to perform the reaction at $115{ }^{\circ} \mathrm{C}$ in toluene in order to reduce the reaction time but the product $2 \mathbf{a}$ was obtain in lower yield (Table 1, entry 11). The use of toluene as solvent at a lower temperature than $100{ }^{\circ} \mathrm{C}$ did not lead to the desired product (Table 1, entry 12-13).

The optimum conditions for the catalytic Diaza-Wittig reaction is the use of $10 \mathrm{~mol} \%$ of $\mathbf{3}$ with diphenylsilane as reducing reagent in toluene at $100{ }^{\circ} \mathrm{C}$ for 16 hours.

Table 1 Optimization of the reaction conditions. ${ }^{a}$

\begin{tabular}{|c|c|c|c|c|c|c|}
\hline & 1a ${ }^{\mathrm{N}_{2}}$ & $\begin{array}{l}\text { a. IBX } \\
\text { b. Ph } \\
\text { sol }\end{array}$ & $\begin{array}{l}\mathrm{CH}_{3} \mathrm{CN}, 2 \mathrm{~h}, \mathrm{r} \\
\text { sphine oxide, } \\
\text { ent, time, tem }\end{array}$ & & $2 a$ & \\
\hline Entry & Catalyst & Silane & Solvent & $\begin{array}{l}\text { Temp. } \\
\left({ }^{\circ} \mathrm{C}\right)^{b}\end{array}$ & $\begin{array}{l}\text { Time } \\
\text { (h) }\end{array}$ & $\begin{array}{l}\text { Yield } \\
(\%)^{c}\end{array}$ \\
\hline 1 & $\mathrm{HMPT}^{d}$ & - & $\mathrm{CH}_{2} \mathrm{Cl}_{2}$ & RT & 16 & $68^{e}$ \\
\hline 2 & $\mathrm{HMPT}^{f}$ & - & $\mathrm{CH}_{2} \mathrm{Cl}_{2}$ & RT & 48 & $13^{e}$ \\
\hline 3 & $\mathrm{HMPA}^{d}$ & - & $\mathrm{CH}_{2} \mathrm{Cl}_{2}$ & $\mathrm{RT}$ & 16 & 0 \\
\hline 4 & $\mathrm{O}=\mathrm{PPh}_{3}{ }^{f}$ & $\mathrm{Ph}_{2} \mathrm{SiH}_{2}$ & Toluene & 100 & 16 & 0 \\
\hline 5 & $\mathrm{HMPA}^{f}$ & $\mathrm{Ph}_{2} \mathrm{SiH}_{2}$ & Toluene & 100 & 16 & 0 \\
\hline 6 & $\mathbf{3}^{g}$ & $\mathrm{PhSiH}_{3}$ & Toluene & 100 & 16 & $46^{e}$ \\
\hline 7 & $\mathbf{3}^{g}$ & $\mathrm{Ph}_{2} \mathrm{SiH}_{2}$ & $\mathrm{CH}_{2} \mathrm{Cl}_{2}$ & RT & 16 & 0 \\
\hline 8 & $\mathbf{3}^{g}$ & $\mathrm{Ph}_{2} \mathrm{SiH}_{2}$ & $\mathrm{CH}_{3} \mathrm{CN}$ & 65 & 16 & 0 \\
\hline 9 & $\mathbf{3}^{g}$ & $\mathrm{Ph}_{2} \mathrm{SiH}_{2}$ & DMF & 100 & 16 & $71^{e}$ \\
\hline 10 & $\mathbf{3}^{g}$ & $\mathrm{Ph}_{2} \mathrm{SiH}_{2}$ & Dioxane & 100 & 16 & $74^{e}$ \\
\hline 11 & $\mathbf{3}^{g}$ & $\mathrm{Ph}_{2} \mathrm{SiH}_{2}$ & Toluene & $115^{h}$ & 16 & $64^{i}$ \\
\hline 12 & $\mathbf{3}^{g}$ & $\mathrm{Ph}_{2} \mathrm{SiH}_{2}$ & Toluene & RT & 16 & 0 \\
\hline 13 & $\mathbf{3}^{g}$ & $\mathrm{Ph}_{2} \mathrm{SiH}_{2}$ & Toluene & 65 & 16 & 0 \\
\hline 14 & $\mathbf{3}^{g}$ & $\mathrm{Ph}_{2} \mathrm{SiH}_{2}$ & Toluene & 100 & 16 & $92^{i}$ \\
\hline 15 & $\mathbf{3}^{g}$ & $\mathrm{Ph}_{2} \mathrm{SiH}_{2}$ & Toluene & 100 & 48 & $95^{i, j}$ \\
\hline 16 & $3^{g}$ & $-{ }^{k}$ & Toluene & 100 & 16 & 0 \\
\hline
\end{tabular}

${ }^{a}$ See supporting information for details. ${ }^{b}$ Temperature of the oil bath. ${ }^{c}$ Yield of isolated product is quoted as an average over at least two experiments. ${ }^{d}$ Stoichiometric amounts of organophosphorus reagent were used. ${ }^{e}$ Purification by flash chromatography on silica gel. ${ }^{f}$ Catalytic amounts $(25 \mathrm{~mol} \%)$ were used. ${ }^{8}$ Catalytic amounts $(10 \mathrm{~mol}$ $\%$ ) were used. ${ }^{h}$ Reaction was performed in a sealed tube at $115{ }^{\circ} \mathrm{C}$. ${ }^{i}$ Precipitation of $\mathbf{2 a} .{ }^{j}$ Addition of $10 \mathrm{~mol} \%$ of $\mathbf{3}$ to the initial amount after $24 \mathrm{~h}$ of reaction. ${ }^{k}$ Control reaction without silane reagent. 
The amount of catalyst used so far was always $10 \mathrm{~mol} \%$ of $\mathbf{3}$. To assess this method further, it was necessary to vary the loading of the phospholene oxide $\mathbf{3}$. The conversion of $\mathbf{1 b}$ into 2b was used for this optimization process.

Table 2 Optimization of the loading of the catalyst $\mathbf{3}^{a}$

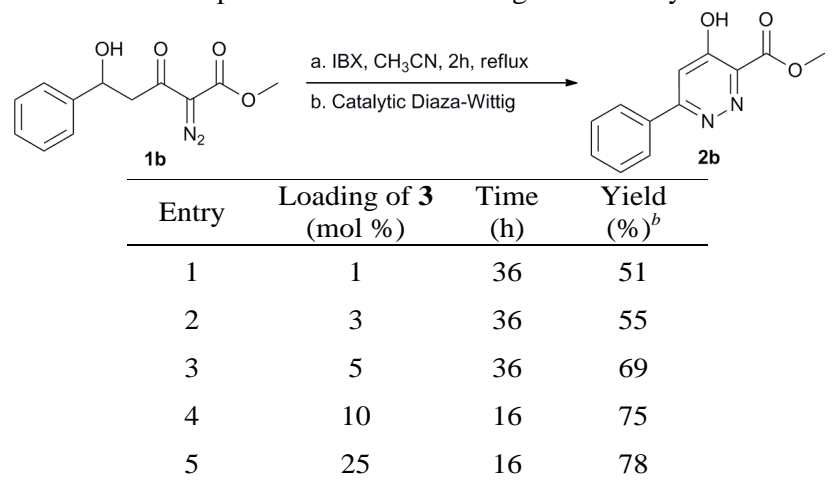

${ }^{a}$ See supporting information for details. ${ }^{b}$ Yield of isolated product is quoted as an average over at least two experiments.

The organophosphorus-catalyzed Diaza-Wittig reaction was performed following the optimum conditions previously discussed and the amount of catalyst $\mathbf{3}$ was varied. The use of $\mathbf{1 b}$ as starting material led to the desired product $\mathbf{2 b}$ in $75 \%$ yield with $10 \mathrm{~mol} \%$ of $\mathbf{3}$ (Table 2 , entry 4). Increasing the amount of $\mathbf{3}$ to $25 \mathrm{~mol} \%$ gave almost similar results (Table 2, entry 5), and a decrease below $10 \mathrm{~mol} \%$ of the phospholene oxide 3 (Table 2, entry 2-3), likewise, led to product formation but in longer reaction time. The use of $1 \mathrm{~mol} \%$ of catalyst 3 afforded $\mathbf{2 b}$ in $51 \%$ after 36 hours (Table 2, entry 1).

We then focused on the synthesis of a small library of pyridazine derivatives 2 to evaluate the catalytic Diaza-Wittig reaction with different substrates.

Most of the pyridazines were obtained as precipitate in good (2k) to excellent yields (2a). Only compounds $\mathbf{2 c}, \mathbf{2 h}$ and $\mathbf{2 n}$ needed to be purified by flash chromatography on silica gel. The organophosphorus-catalyzed Diaza-Wittig reaction was compatible with different substitutions $\mathrm{R}^{2}$, from alkyl (2a, 2l), cycloalkyl (2c, $\mathbf{2 h})$, aryl (2d, $\mathbf{2 j}$ ) to heteroaryl (2m). It was also possible to perform the reaction in the presence of different functional groups such as ester (2i), ketone (2k) or substituted sulfone (2n) which allow further modification in order to obtain more elaborated pyridazine analogues. The catalytic reaction was not affected by the use of ortho-substituted $(\mathbf{2} \mathbf{e}, \mathbf{2 j}$ ) or para-substituted aryl groups $(\mathbf{2 d}, \mathbf{2} \mathbf{i})$ affording the products in similar yields. Moreover, the cyclization gave access to trisubstituted (2d) as well as tetrasubstituted (2f) heterocycles by varying $\mathrm{R}^{1}$. Finally, the process reported was applied to the synthesis of annulated pyridazine (2o) and led to the desired product in good yield (Table 3).
Table 3 Substrate scope of the catalytic Diaza-Wittig reaction. ${ }^{a}$

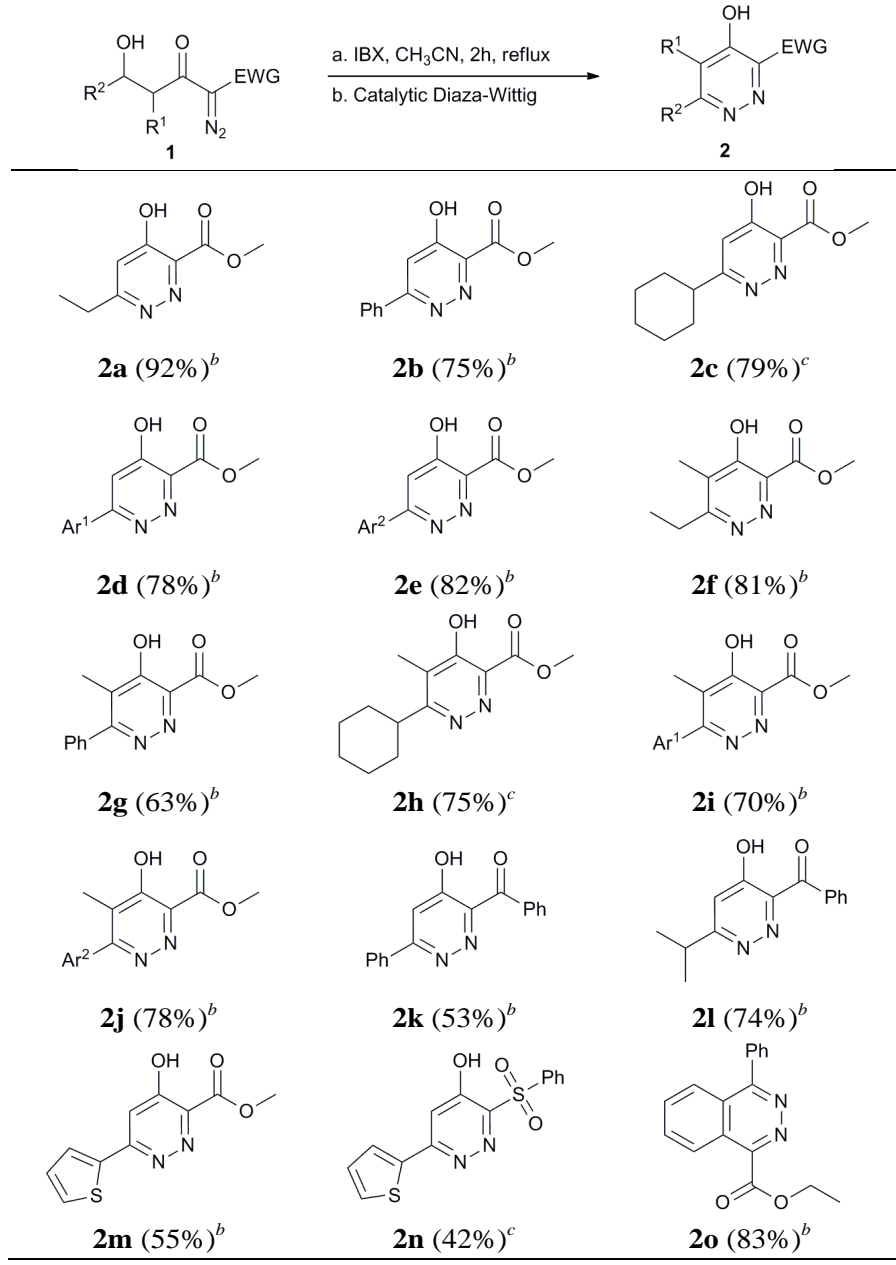

${ }^{a}$ See supporting information for details, yields of isolated product are quoted as an average over at least two experiments. ${ }^{b}$ Precipitation of $\mathbf{2}$. ${ }^{c}$ Purification by flash chromatography on silica gel. $\mathrm{Ph}=$ phenyl, $\mathrm{Ar}^{1}=$ $p$-methoxyphenyl, $\mathrm{Ar}^{2}=o$-fluorophenyl.

\section{Conclusions}

In summary, we reported the first organophosphorus-catalyzed Diaza-Wittig reaction and its application for the synthesis of pyridazine analogues. The reaction tolerated various substituents and functional groups and delivered most of the derivatives without purification.

This method represents a novel catalytic approach to relevant heterocycles known as "privileged structures" for the pharmaceutical industry. Further studies are under investigation towards other heterocycles.

\section{Experimental section}

\section{General information}

For all reactions, analytical grade solvents were used. All moisture-sensitive reactions were carried out in oven-dried glassware $\left(135{ }^{\circ} \mathrm{C}\right)$ under a nitrogen or argon atmosphere. Reaction temperatures are reported as bath temperature. Precoated aluminum sheets (Silica gel/TLC-cards, $254 \mathrm{~nm}$ ) were used for TLC. Compounds were visualized with UV light 
$(\lambda=254 \mathrm{~nm})$. Products were purified by flash chromatography on silica gel 63-200, $60 \AA$. Melting points were obtained on a melting point apparatus with open capillary tubes. ${ }^{1} \mathrm{H}$ and ${ }^{13} \mathrm{C}$ NMR spectra were recorded on $300 \mathrm{MHz}, 500 \mathrm{MHz}$ and 600 $\mathrm{MHz}$ spectrometer using $\mathrm{CDCl}_{3}$ and DMSO- $d_{6}$ as the solvent. The ${ }^{1} \mathrm{H}$ and ${ }^{13} \mathrm{C}$ chemical shifts were referenced to residual solvent signals at $\delta \mathrm{H} / \mathrm{C} 7.26 / 77.00\left(\mathrm{CDCl}_{3}\right)$ and $2.50 / 39.50$ (DMSO- $d_{6}$ ) relative to TMS as internal standard. Coupling constants $J(\mathrm{~Hz})$ were directly taken from the spectra. Splitting patterns are designated as s (singlet), d (doublet), $\mathrm{t}$ (triplet), $\mathrm{q}$ (quartet), $\mathrm{m}$ (multiplet) and br (broad). High resolution mass spectra were acquired on a quadrupole orthogonal acceleration time-of-flight mass spectrometer. Samples were infused at 3 $\mu \mathrm{L} / \mathrm{min}$ and spectra were obtained in positive (or negative) ionization mode with a resolution of 15000 (FWHM) using leucine enkephalin as lock mass. Electrospray MS spectra were obtained on a LC/MS spectrometer. Column used for all LC/MS analysis: UPLC BEH C18 $1.7 \mu \mathrm{m}, 2.1 \mathrm{~mm}$ ID x $50 \mathrm{~mm}$ L. All the methods are using $\mathrm{MeCN} / \mathrm{H}_{2} \mathrm{O}$ gradients. Water contains either $0.1 \%$ TFA or $0.1 \% \mathrm{NH}_{3}$.

Methyl 2-diazo-3-oxobutanoate. To a solution of methyl acetoacetate $(5 \mathrm{~g}, 43.06 \mathrm{mmol})$ in $30 \mathrm{~mL}$ of acetonitrile under argon at $0{ }^{\circ} \mathrm{C}$ was added successively triethylamine $(7.8 \mathrm{~mL}$, $55.98 \mathrm{mmol})$ and $p$-acetamido benzene sulfonyl azide ( $p$ ABSA) (10.4 g, $43.06 \mathrm{mmol}$ ). The mixture was stirred for 2 hours and was allowed to warm to room temperature and was diluted with $100 \mathrm{~mL}$ of $\mathrm{Et}_{2} \mathrm{O} / n$-Hexane (1:1) and then filtered. The filtrate was concentrated and the residue purified by flash column chromatography on silica gel $($ EtOAc/ $n$-Hexane $=1: 2)$ to afford the desired compound methyl 2-diazo-3-oxobutanoate (5 g, $35.18 \mathrm{mmol}, 82 \%$ yield) as yellow oil. Data for methyl 2diazo-3-oxobutanoate: ${ }^{1} \mathrm{H}$ NMR (500 MHz, DMSO- $\left.d_{6}\right) \delta 3.65$ $(3 \mathrm{H}, \mathrm{s}), 2.18(3 \mathrm{H}, \mathrm{s}) ;{ }^{13} \mathrm{C}$ NMR $\left(125 \mathrm{MHz}, \mathrm{DMSO}-d_{6}\right) \delta 189.3$, $161.5,52.3,27.9$. Diazo carbon was not detected in ${ }^{13} \mathrm{C}$ NMR.

Methyl 2-diazo-3-oxopentanoate. To a solution of methyl 3oxopentanoate $(5 \mathrm{~g}, 38.42 \mathrm{mmol})$ in $30 \mathrm{~mL}$ of acetonitrile under argon at $0{ }^{\circ} \mathrm{C}$ was added successively triethylamine $(6.9 \mathrm{~mL}$, $49.95 \mathrm{mmol}$ ) and $p$-acetamido benzene sulfonyl azide ( $p$ ABSA) (9.2 g, $38.42 \mathrm{mmol}$ ). The mixture was stirred for 2 hours and was allowed to warm to room temperature and was diluted with $100 \mathrm{~mL}$ of $\mathrm{Et}_{2} \mathrm{O} / n$-Hexane $(1: 1)$ and then filtered. The filtrate was concentrated and the residue purified by flash column chromatography on silica gel $($ EtOAc/ $n$-Hexane $=1: 2)$ to afford the desired compound methyl 2-diazo-3oxopentanoate $(5.1 \mathrm{~g}, 33.04 \mathrm{mmol}, 85 \%$ yield) as yellow oil. Data for methyl 2-diazo-3-oxopentanoate: ${ }^{1} \mathrm{H}$ NMR $(300 \mathrm{MHz}$, DMSO- $\left.d_{6}\right) \delta 3.77(3 \mathrm{H}, \mathrm{s}), 2.78(2 \mathrm{H}, \mathrm{q}, J=7.3 \mathrm{~Hz}), 1.02(3 \mathrm{H}, \mathrm{t}$, $J=7.3 \mathrm{~Hz}) ;{ }^{13} \mathrm{C}$ NMR $\left(75 \mathrm{MHz}, \mathrm{DMSO}-d_{6}\right) \delta 192.5,161.5$, $52.3,33.0,8.2$. Diazo carbon was not detected in ${ }^{13} \mathrm{C}$ NMR.

2-Diazo-1-phenylbutane-1,3-dione. To a solution of phenylbutan-2,4-dione $(3 \mathrm{~g}, 18.50 \mathrm{mmol})$ in $50 \mathrm{~mL}$ of acetonitrile under argon at $0{ }^{\circ} \mathrm{C}$ was added successively triethylamine (3.3 $\mathrm{mL}, 24.05 \mathrm{mmol})$ and $p$-acetamido benzene sulfonyl azide ( $p$ ABSA) (4.4 g, $18.50 \mathrm{mmol}$ ). The mixture was stirred for 2 hours and was allowed to warm to room temperature and was diluted with $100 \mathrm{~mL}$ of $\mathrm{Et}_{2} \mathrm{O} / n$-Hexane $(1: 1)$ and then filtered. The filtrate was concentrated and the residue purified by flash column chromatography on silica gel $($ EtOAc/ $n$-Hexane $=1: 3)$ to afford the desired 2-Diazo-1-phenylbutane-1,3-dione (3.1 g, $16.45 \mathrm{mmol}, 89 \%$ yield) as yellow solid; $\mathrm{mp} 78-81{ }^{\circ} \mathrm{C}$; Data for 2-Diazo-1-phenylbutane-1,3-dione: ${ }^{1} \mathrm{H}$ NMR $(500 \mathrm{MHz}$, DMSO-d $) \delta 7.73(2 \mathrm{H}, \mathrm{d}, J=7.2 \mathrm{~Hz}), 7.62(1 \mathrm{H}, \mathrm{t}, J=7.4 \mathrm{~Hz})$, 7.52-7.55 (2H, m), $2.46(3 \mathrm{H}, \mathrm{s}) ;{ }^{13} \mathrm{C}$ NMR (125 MHz, DMSO$\left.d_{6}\right) \delta 189.8,185.0,137.5,132.5,128.8,127.6,83.6,28.8$.

\section{Typical experimental procedure for the synthesis of 1a-e and $1 \mathrm{~m}$}

To a solution of methyl 2-diazo-3-oxobutanoate (1 g, 7.04 mmol) in $50 \mathrm{~mL}$ of $\mathrm{CH}_{2} \mathrm{Cl}_{2}$ under argon at $-78{ }^{\circ} \mathrm{C}$ was added dropwise $\mathrm{TiCl}_{4}(849 \mu \mathrm{L}, 7.74 \mathrm{mmol})$ followed by $\mathrm{Et}_{3} \mathrm{~N}$ (1.08 $\mathrm{mL}, 7.74 \mathrm{mmol})$. The resulting red solution was stirred at -78 ${ }^{\circ} \mathrm{C}$ for 1 hour, after which time a solution of aldehyde (6.34 mmol) in $\mathrm{CH}_{2} \mathrm{Cl}_{2}$ was slowly added. The reaction mixture was stirred at $-78{ }^{\circ} \mathrm{C}$ for 4 hours and then the reaction was quenched with $50 \mathrm{~mL}$ of saturated aqueous $\mathrm{NH}_{4} \mathrm{Cl}$ and warmed to room temperature. The organic layer was separated and then washed with $40 \mathrm{~mL}$ of saturated aqueous $\mathrm{NaHCO}_{3}$. The aqueous layers were extracted with $50 \mathrm{~mL}$ of $\mathrm{CH}_{2} \mathrm{Cl}_{2}$. The combined organic layers were dried over $\mathrm{Na}_{2} \mathrm{SO}_{4}$ and concentrated in vacuo. The product was purified by flash column chromatography on silica gel $($ EtOAc/ $n$-Hexane $=1: 3)$ to afford the aldol product 1a-e and $\mathbf{1 m}$.

Methyl 2-diazo-5-hydroxy-3-oxoheptanoate (1a). Yellow oil; Yield: 85\%; Synthesized from propionaldehyde. Spectral and analytical data were in agreement with previous reports. ${ }^{8}$

Methyl 2-diazo-5-hydroxy-3-oxo-5-phenylpentanoate (1b). Yellow oil; Yield: 75\%; Synthesized from benzaldehyde. Spectral and analytical data were in agreement with previous reports. ${ }^{8}$

Methyl 5-cyclohexyl-2-diazo-5-hydroxy-3-oxopentanoate (1c). Yellow oil; Yield: 73\%; Synthesized from cyclohexane carboxaldehyde. Spectral and analytical data were in agreement with previous reports. ${ }^{8}$

Methyl 2-diazo-5-hydroxy-5-(4-methoxyphenyl)-3oxopentanoate (1d). Yellow oil; Yield: 71\%; Synthesized from 4-methoxybenzaldehyde. Spectral and analytical data were in agreement with previous reports. ${ }^{8}$

Methyl 2-diazo-5-(2-fluorophenyl)-5-hydroxy-3oxopentanoate (1e). Yellow oil; Yield: 69\%; ${ }^{1} \mathrm{H}$ NMR (300 $\left.\mathrm{MHz}, \mathrm{DMSO}-d_{6}\right) \delta$ 7.50-7.55 $(1 \mathrm{H}, \mathrm{m}), 7.27-7.30(1 \mathrm{H}, \mathrm{m}), 7.10-$ $7.23(2 \mathrm{H}, \mathrm{m}), 5.51(1 \mathrm{H}, \mathrm{d}, J=5.0 \mathrm{~Hz}), 5.33-5.39(1 \mathrm{H}, \mathrm{m}), 3.77$ (3H, s), 3.34-3.43 (1H, m), $2.93(1 \mathrm{H}, \mathrm{dd}, J=15.8 \mathrm{~Hz}, J=4.2$ $\mathrm{Hz}) ;{ }^{13} \mathrm{C}$ NMR (75 MHz, DMSO- $\left.d_{6}\right) \delta 189.3,161.4,160.7$, 157.4, 131.8, 129.0, 127.9, 124.5, 115.2, 75.9, 62.6, 52.4, 47.6; HRMS calcd for $\mathrm{C}_{12} \mathrm{H}_{11} \mathrm{FN}_{2} \mathrm{O}_{4}(\mathrm{M}+\mathrm{Na})^{+}$289.0595, found 289.0598 .

Methyl 2-diazo-5-hydroxy-5-(thiophene-2-yl)-3oxopentanoate (1m). Yellow oil; Yield: 54\%; Synthesized from thiophene-2-carboxaldehyde. Spectral and analytical data were in agreement with previous reports. ${ }^{8}$

\section{Typical experimental procedure for the synthesis of $1 \mathrm{f}-\mathrm{j}$}

To a solution of methyl 2-diazo-3-oxopentanoate (1 g, 6.40 $\mathrm{mmol})$ in $50 \mathrm{~mL}$ of $\mathrm{CH}_{2} \mathrm{Cl}_{2}$ under argon at $-78{ }^{\circ} \mathrm{C}$ was added dropwise $\mathrm{TiCl}_{4}(772 \mu \mathrm{L}, 7.04 \mathrm{mmol})$ followed by $\mathrm{Et}_{3} \mathrm{~N}$ (979 $\mu \mathrm{L}, 7.04 \mathrm{mmol})$. The resulting red solution was stirred at $-78^{\circ} \mathrm{C}$ for 1 hour, after which time a solution of aldehyde $(5.76 \mathrm{mmol})$ 
in $\mathrm{CH}_{2} \mathrm{Cl}_{2}$ was slowly added. The reaction mixture was stirred at $-78{ }^{\circ} \mathrm{C}$ for 4 hours and then the reaction was quenched with $20 \mathrm{~mL}$ of saturated aqueous $\mathrm{NH}_{4} \mathrm{Cl}$ and warmed to room temperature. The organic layer was separated and then washed with $20 \mathrm{~mL}$ of saturated aqueous $\mathrm{NaHCO}_{3}$. The aqueous layers were extracted with $20 \mathrm{~mL}$ of $\mathrm{CH}_{2} \mathrm{Cl}_{2}$. The combined organic layers were dried over $\mathrm{Na}_{2} \mathrm{SO}_{4}$ and concentrated in vacuo. The product was purified by flash column chromatography on silica gel $(\mathrm{EtOAc} / n-\mathrm{Hexane}=1: 3)$ to afford the aldol product $\mathbf{1 f}-\mathbf{j}$.

Methyl 2-diazo-5-hydroxy-4-methyl-3-oxoheptanoate (1f). Yellow oil; Yield: 88\%; Inseparable diastereomeric mixture; ${ }^{1} \mathrm{H}$ NMR (300 MHz, DMSO-d $)_{6} \delta 4.54(1 \mathrm{H}, \mathrm{d}, J=6.2 \mathrm{~Hz}), 3.77$ $(3 \mathrm{H}, \mathrm{s}), 3.48-3.60(2 \mathrm{H}, \mathrm{m}), 1.25-1.42(2 \mathrm{H}, \mathrm{m}), 1.01(3 \mathrm{H}, \mathrm{d}, J=$ $6.6 \mathrm{~Hz}), 0.86(3 \mathrm{H}, \mathrm{t}, J=6.4 \mathrm{~Hz}) ;{ }^{13} \mathrm{C} \mathrm{NMR}(75 \mathrm{MHz}, \mathrm{DMSO}-$ $\left.d_{6}\right) \delta 194.6,161.4,72.4,52.3,47.1,27.9,11.6,10.6$; HRMS calcd for $\mathrm{C}_{9} \mathrm{H}_{14} \mathrm{~N}_{2} \mathrm{O}_{4}(\mathrm{M}+\mathrm{Na})^{+}$237.0846, found 237.0851 . Diazo carbon was not detected in ${ }^{13} \mathrm{C}$ NMR.

Methyl

2-diazo-5-hydroxy-4-methyl-3-oxo-5phenylpentanoate (1g). Yellow oil; Yield: 72\%; Synthesized from benzaldehyde. Spectral and analytical data were in agreement with previous reports. ${ }^{22}$

Methyl 5-cyclohexyl-2-diazo-5-hydroxy-4-methyl-3oxopentanoate (1h). Yellow oil; Yield: 63\%; Inseparable diastereomeric mixture; ${ }^{1} \mathrm{H}$ NMR (300 MHz, DMSO- $\left.d_{6}\right) \delta 4.41$ $(1 \mathrm{H}, \mathrm{d}, J=6.8 \mathrm{~Hz}), 3.78(3 \mathrm{H}, \mathrm{s}), 3.60-3.64(1 \mathrm{H}, \mathrm{m}), 3.42-3.48$ $(1 \mathrm{H}, \mathrm{m}), 1.51-1.87(6 \mathrm{H}, \mathrm{m}), 1.08-1.28(5 \mathrm{H}, \mathrm{m}), 0.98(3 \mathrm{H}, \mathrm{d}, J=$ $6.8 \mathrm{~Hz}) ;{ }^{13} \mathrm{C}$ NMR $\left(75 \mathrm{MHz}, \mathrm{DMSO}-d_{6}\right) \delta 194.6,161.3,75.9$, 74.5, 52.3, 44.7, 41.0, 29.3, 28.4, 26.2, 26.0, 25.9, 10.6; HRMS calcd for $\mathrm{C}_{13} \mathrm{H}_{20} \mathrm{~N}_{2} \mathrm{O}_{4}(\mathrm{M}+\mathrm{Na})^{+} 291.1315$, found 291.1317.

Methyl 2-diazo-5-hydroxy-5-(4-methoxyphenyl)-4-methyl-3oxopentanoate (1i). Yellow oil; Yield: 53\%; ${ }^{1} \mathrm{H}$ NMR (300 $\left.\mathrm{MHz}, \mathrm{DMSO}-d_{6}\right) \delta 7.25(2 \mathrm{H}, \mathrm{d}, J=8.7 \mathrm{~Hz}), 6.87(2 \mathrm{H}, \mathrm{d}, J=$ $8.7 \mathrm{~Hz}), 5.21-5.23(1 \mathrm{H}, \mathrm{m}), 4.79-4.80(1 \mathrm{H}, \mathrm{m}), 3.78(3 \mathrm{H}, \mathrm{s})$, $3.73(3 \mathrm{H}, \mathrm{s}), 3.30-3.31(1 \mathrm{H}, \mathrm{m}), 0.97(3 \mathrm{H}, \mathrm{d}, J=6.8 \mathrm{~Hz}) ;{ }^{13} \mathrm{C}$ NMR (75 MHz, DMSO- $\left.d_{6}\right) \delta 193.5,161.4,158.2,135.9,127.3$, 113.3, 72.3, 55.1, 52.4, 49.3, 11.0; HRMS calcd for $\mathrm{C}_{14} \mathrm{H}_{16} \mathrm{~N}_{2} \mathrm{O}_{5}(\mathrm{M}+\mathrm{Na})^{+} 315.0952$, found 315.0953. Diazo carbon was not detected in ${ }^{13} \mathrm{C}$ NMR.

Methyl 2-diazo-5-(2-fluorophenyl)-5-hydroxy-4-methyl-3oxopentanoate (1j). Yellow oil; Yield: 51\%; ${ }^{1} \mathrm{H}$ NMR (300 MHz, DMSO- $\left.d_{6}\right) \delta 7.47(1 \mathrm{H}, \mathrm{m}), 7.31-7.38(1 \mathrm{H}, \mathrm{m}), 7.22-7.30$ $(1 \mathrm{H}, \mathrm{m}), 7.12-7.18(1 \mathrm{H}, \mathrm{m}), 5.52(1 \mathrm{H}, \mathrm{t}, J=4.4 \mathrm{~Hz}), 5.04-5.09$ $(1 \mathrm{H}, \mathrm{m}), 3.90-3.95(1 \mathrm{H}, \mathrm{m}), 3.80(3 \mathrm{H}, \mathrm{s}), 0.76(2 \mathrm{H}, \mathrm{t}, J=6.9$ $\mathrm{Hz}) ;{ }^{13} \mathrm{C}$ NMR (75 MHz, DMSO-d 6 ) $\delta 194.3,161.3,158.0$, 130.5, 129.3, 128.8, 124.7, 115.1, 75.8, 67.9, 52.4, 47.8, 13.2; HRMS calcd for $\mathrm{C}_{13} \mathrm{H}_{13} \mathrm{FN}_{2} \mathrm{O}_{4}(\mathrm{M}+\mathrm{Na})^{+} 303.0752$, found 303.0751.

\section{Typical experimental procedure for the synthesis of $1 \mathrm{k}-\mathrm{l}$}

To a solution of 2-Diazo-1-phenylbutane-1,3-dione (1 g, 5.31 mmol) in $50 \mathrm{~mL}$ of $\mathrm{CH}_{2} \mathrm{Cl}_{2}$ under argon at $-78{ }^{\circ} \mathrm{C}$ was added dropwise $\mathrm{TiCl}_{4}(640 \mu \mathrm{L}, 5.84 \mathrm{mmol})$ followed by $\mathrm{Et}_{3} \mathrm{~N}(812$ $\mu \mathrm{L}, 5.84 \mathrm{mmol})$. The resulting red solution was stirred at $-78{ }^{\circ} \mathrm{C}$ for 1 hour, after which time a solution of aldehyde $(4.78 \mathrm{mmol})$ in $\mathrm{CH}_{2} \mathrm{Cl}_{2}$ was slowly added. The reaction mixture was stirred at $-78{ }^{\circ} \mathrm{C}$ for 4 hours and then the reaction was quenched with $50 \mathrm{~mL}$ of saturated aqueous $\mathrm{NH}_{4} \mathrm{Cl}$ and warmed to room temperature. The organic layer was separated and then washed with $40 \mathrm{~mL}$ of saturated aqueous $\mathrm{NaHCO}_{3}$. The aqueous layers were extracted with $50 \mathrm{~mL}$ of $\mathrm{CH}_{2} \mathrm{Cl}_{2}$. The combined organic layers were dried over $\mathrm{Na}_{2} \mathrm{SO}_{4}$ and concentrated in vacuo. The product was purified by flash column chromatography on silica gel $($ EtOAc/ $n$-Hexane $=1: 4)$ to afford the aldol product 1k-l.

2-Diazo-5-hydroxy-1,5-diphenylpentane-1,3-dione (1k). Yellow oil; Yield: 52\%; Synthesized from benzaldehyde. Spectral and analytical data were in agreement with previous reports. $^{7}$

\section{2-Diazo-5-hydroxy-6-methyl-1-phenylheptane-1,3-dione} (11). Yellow oil; Yield: 85\%; Synthesized from isobutyraldehyde. Spectral and analytical data were in agreement with previous reports. ${ }^{7}$

\section{Typical experimental procedure for the organophosphorus-} catalyzed Diaza-Wittig reaction

To a solution of 1 ( $1 \mathrm{mmol})$ in $10 \mathrm{~mL}$ of acetonitrile under argon was added IBX (1-hydroxy-1,2-benziodoxol-3(1H)-one 1-oxide) (364 mg, $1.3 \mathrm{mmol}$ ). The mixture was refluxed for 2 hours and was allowed to cool down to room temperature and then filtered. The filtrate was concentrated and used directly without further purification for the next step.

To the previously prepared crude in $5 \mathrm{~mL}$ of toluene under argon was added $\mathbf{3}$ (19 $\mathrm{mg}, 0.1 \mathrm{mmol}$ ) followed by diphenylsilane $(205 \mu \mathrm{L}, 1.1 \mathrm{mmol})$. The reaction mixture was heated at $100{ }^{\circ} \mathrm{C}$ for 16 hours. After completion of the reaction monitored by TLC, the reaction mixture was allowed to cool to room temperature and the formation of a precipitate was observed. The suspension was filtered, washed with diisopropyl ether and dried to afford the desired pyridazine $\mathbf{2 a}, \mathbf{2 b}, \mathbf{2 d}, \mathbf{2 e}$, 2f, $2 \mathrm{~g}, 2 \mathbf{i}, 2 \mathrm{j}, 2 \mathrm{k}, 2 \mathrm{l}$ and $2 \mathrm{~m}$.

2c and $\mathbf{2 h}$ were purified by flash column chromatography on silica gel $(\mathrm{EtOAc} / \mathrm{MeOH}=9: 1)$ due to no formation of precipitate.

Methyl 6-ethyl-4-hydroxypyridazine-3-carboxylate (2a). White solid; Yield: 92\%; mp 179-182 ${ }^{\circ} \mathrm{C}$. Spectral and analytical data were in agreement with previous reports. ${ }^{8}$

Methyl 4-hydroxy-6-phenylpyridazine-3-carboxylate (2b). Pale yellow solid; Yield: 75\%; mp 211-212 ${ }^{\circ} \mathrm{C}$. Spectral and analytical data were in agreement with previous reports. ${ }^{8}$

Methyl 6-cyclohexyl-4-hydroxypyridazine-3-carboxylate (2c). Beige solid; Yield: 79\%; mp 215-217 ${ }^{\circ} \mathrm{C}$. Spectral and analytical data were in agreement with previous reports. ${ }^{8}$

Methyl 4-hydroxy-6-(4-methoxyphenyl)pyridazine-3carboxylate (2d). Pale yellow solid; Yield: 78\%; mp 214-216 ${ }^{\circ} \mathrm{C}$. Spectral and analytical data were in agreement with previous reports. ${ }^{8}$

Methyl 6-(2-fluorophenyl)-4-hydroxypyridazine-3carboxylate (2e). Pale yellow solid; Yield: 82\%; mp 220-224 ${ }^{\circ} \mathrm{C} ;{ }^{1} \mathrm{H}$ NMR (300 MHz, DMSO-d $) \delta 13.77$ (1H, br. s), 7.65$7.73(2 \mathrm{H}, \mathrm{m}), 7.39-7.49(2 \mathrm{H}, \mathrm{m}), 6.74(1 \mathrm{H}, \mathrm{s}), 3.86(3 \mathrm{H}, \mathrm{s}) ;{ }^{13} \mathrm{C}$ NMR (75 MHz, DMSO-d $\left.d_{6}\right) \delta 164.0,160.7,157.4,133.5,133.4$, 131.0, 130.9, 125.4, 125.3, 118.9, 116.5, 52.6; HRMS calcd for $\mathrm{C}_{12} \mathrm{H}_{9} \mathrm{FN}_{2} \mathrm{O}_{3}(\mathrm{M}+\mathrm{H})^{+} 249.0670$, found 249.0675 . 
Methyl

6-ethyl-4-hydroxy-5-methylpyridazine-3carboxylate (2f). White solid; Yield: $81 \%$; mp $175-179{ }^{\circ} \mathrm{C} ;{ }^{1} \mathrm{H}$ NMR (300 MHz, DMSO-d $\left.d_{6}\right) \delta 13.27$ (1H, br. s), $3.80(3 \mathrm{H}, \mathrm{s})$, $2.64(2 \mathrm{H}, \mathrm{q}, J=7.5 \mathrm{~Hz}), 1.93(3 \mathrm{H}, \mathrm{s}), 1.17(3 \mathrm{H}, \mathrm{t}, J=7.5 \mathrm{~Hz})$; ${ }^{13} \mathrm{C}$ NMR (75 MHz, DMSO- $\left.d_{6}\right) \delta 167.4,164.6,152.8,145.7$, 125.9, 52.3, 22.5, 12.8, 9.3; HRMS calcd for $\mathrm{C}_{9} \mathrm{H}_{12} \mathrm{~N}_{2} \mathrm{O}_{3}$ $(\mathrm{M}+\mathrm{H})^{+}$197.0921, found 197.0927.

Methyl 4-hydroxy-5-methyl-6-phenylpyridazine-3carboxylate (2g). White solid; Yield: 63\%; mp 239-244 ${ }^{\circ} \mathrm{C} ;{ }^{1} \mathrm{H}$ NMR (300 MHz, DMSO- $\left.d_{6}\right) \delta 13.54(1 \mathrm{H}$, br. s), $7.57-7.58(5 \mathrm{H}$, $\mathrm{m}), 3.84(3 \mathrm{H}, \mathrm{s}), 1.85(3 \mathrm{H}, \mathrm{s}) ;{ }^{13} \mathrm{C}$ NMR $\left(75 \mathrm{MHz}, \mathrm{DMSO}-d_{6}\right)$ $\delta 167.8,164.4,149.8,145.5,130.9,130.4,129.2,128.9,126.8$, $52.4,11.3$; HRMS calcd for $\mathrm{C}_{13} \mathrm{H}_{12} \mathrm{~N}_{2} \mathrm{O}_{3}(\mathrm{M}+\mathrm{H})^{+} 245.0921$, found 245.0921 .

Methyl 6-cyclohexyl-4-hydroxy-5-methylpyridazine-3carboxylate (2h). White solid; Yield: $75 \%$; mp 243-247 ${ }^{\circ} \mathrm{C} ;{ }^{1} \mathrm{H}$ NMR (300 MHz, DMSO-d $)_{6} \delta 12.97$ (1H, br. s), 3.80 (3H, s), 2.82-2.90 (1H, m), $1.97(3 \mathrm{H}, \mathrm{s}), 1.56-1.83(7 \mathrm{H}, \mathrm{m}), 1.20-1.44$ $(3 \mathrm{H}, \mathrm{m}) ;{ }^{13} \mathrm{C}$ NMR $\left(75 \mathrm{MHz}, \mathrm{DMSO}-d_{6}\right) \delta 167.4,164.5,154.7$, 145.3, 125.4, 52.3, 38.4, 29.7, 25.9, 25.2, 9.3; HRMS calcd for $\mathrm{C}_{13} \mathrm{H}_{18} \mathrm{~N}_{2} \mathrm{O}_{3}(\mathrm{M}+\mathrm{H})^{+} 251.1390$, found 251.1391.

Methyl 4-hydroxy-6-(4-methoxyphenyl)-5methylpyridazine-3-carboxylate (2i). White solid; Yield: 70\%; mp 223-226 ${ }^{\circ} \mathrm{C}$; ${ }^{1} \mathrm{H}$ NMR (600 MHz, DMSO- $\left.d_{6}\right) \delta 13.45$ $(1 \mathrm{H}$, br. s), $7.49(2 \mathrm{H}, \mathrm{d}, J=8.8 \mathrm{~Hz}), 7.12(2 \mathrm{H}, \mathrm{d}, J=8.8 \mathrm{~Hz})$, $3.84(3 \mathrm{H}, \mathrm{s}), 3.83(3 \mathrm{H}, \mathrm{s}), 1.86(3 \mathrm{H}, \mathrm{s}) ;{ }^{13} \mathrm{C}$ NMR $(150 \mathrm{MHz}$, DMSO- $\left.d_{6}\right) \delta 167.8,164.4,160.7,149.6,145.3,130.7,126.6$, $122.9,114.2,55.5,52.3,11.3$; HRMS calcd for $\mathrm{C}_{14} \mathrm{H}_{14} \mathrm{~N}_{2} \mathrm{O}_{4}$ $(\mathrm{M}+\mathrm{H})^{+}$275.1026, found 275.1028 .

Methyl 6-(2-fluorophenyl)-4-hydroxy-5-methylpyridazine3-carboxylate (2j). White solid; Yield: 78\%; mp 231-233 ${ }^{\circ} \mathrm{C}$; ${ }^{1} \mathrm{H}$ NMR (300 MHz, DMSO- $\left.d_{6}\right) \delta 13.70(1 \mathrm{H}$, br. s), 7.60-7.71 $(2 \mathrm{H}, \mathrm{m}), 7.41-7.50(2 \mathrm{H}, \mathrm{m}), 3.85(3 \mathrm{H}, \mathrm{s}), 1.78(3 \mathrm{H}, \mathrm{s}) ;{ }^{13} \mathrm{C}$ NMR $\left(75 \mathrm{MHz}, \mathrm{DMSO}-d_{6}\right) \delta 167.5,164.3,160.6,157.3,145.7$, $144.5,133.2,131.5,128.6,125.2,118.3,116.2,52.5,11.2$; HRMS calcd for $\mathrm{C}_{13} \mathrm{H}_{11} \mathrm{FN}_{2} \mathrm{O}_{3}(\mathrm{M}+\mathrm{H})^{+}$263.0826, found 263.0826

3-Benzoyl-6-phenylpyridazin-4-ol (2k). Beige solid; Yield: $53 \%$; mp 201-204 ${ }^{\circ} \mathrm{C}$. Spectral and analytical data were in agreement with previous reports. ${ }^{7}$

3-Benzoyl-6-(propan-2-yl)pyridazin-4-ol (2l). Beige solid; Yield: $74 \%$; $\mathrm{mp} 228-231{ }^{\circ} \mathrm{C}$. Spectral and analytical data were in agreement with previous reports. ${ }^{7}$

Methyl 4-hydroxy-6-(thiophene-2-yl)-pyridazine-3carboxylate (2m). Beige solid; Yield: 55\%; mp 207-209 ${ }^{\circ} \mathrm{C}$. Spectral and analytical data were in agreement with previous reports. ${ }^{8}$

\section{Typical experimental procedure for the synthesis of $2 \mathrm{n}$}

4-hydroxy-1-phenylsulfonyl-4-(thiophene-2-yl)-2-butanone. To a solution of lithium diisopropylamine $2 \mathrm{M}(1.1 \mathrm{~mL}, 2.2$ $\mathrm{mmol})$ in $40 \mathrm{~mL}$ of anhydrous THF at $-78{ }^{\circ} \mathrm{C}$ was added dropwise a solution of 1-phenylsulfonyl-2-propanone $(198 \mathrm{mg}$, $1.0 \mathrm{mmol}$ ) in $10 \mathrm{~mL}$ of THF. After $4 \mathrm{~h}$ at $-78{ }^{\circ} \mathrm{C}$, a solution of thiophene-2-carboxaldehyde $(101 \mu \mathrm{L}, 1.1 \mathrm{mmol})$ in THF was added to the resulting orange heterogenous solution and the reaction mixture was allowed to warm to room temperature overnight. Hydrolysis was achieved at $0{ }^{\circ} \mathrm{C}$ with $30 \mathrm{~mL}$ of saturated aqueous $\mathrm{NH}_{4} \mathrm{Cl}$, followed by an addition of AcOEt. The organic layer was dried over $\mathrm{Na}_{2} \mathrm{SO}_{4}$ and concentrated in vacuo, the residue was purified by flash column chromatography on silica gel (EtOAc/ $n$-Hexane $=1: 3$ ) to afford the desired compound 4-hydroxy-1-phenylsulfonyl-4(thiophene-2-yl)-2-butanone (158 $\mathrm{mg}, 0.51 \mathrm{mmol}, 51 \%$ yield) as yellow oil; Data for 4-hydroxy-1-phenylsulfonyl-4(thiophene-2-yl)-2-butanone: ${ }^{1} \mathrm{H}$ NMR (500 MHz, DMSO- $d_{6}$ ) $\delta 7.88(2 \mathrm{H}, \mathrm{d}, J=7.2 \mathrm{~Hz}), 7.76(1 \mathrm{H}, \mathrm{t}, J=7.4 \mathrm{~Hz}), 7.65(2 \mathrm{H}, \mathrm{t}$, $J=7.2 \mathrm{~Hz}), 7.38-7.40(1 \mathrm{H}, \mathrm{m}), 6.93-6.96(1 \mathrm{H}, \mathrm{m}), 6.89-6.90$ $(1 \mathrm{H}, \mathrm{m}), 5.84(1 \mathrm{H}, \mathrm{d}, J=5.1 \mathrm{~Hz}), 5.18-5.24(1 \mathrm{H}, \mathrm{m}), 4.76(2 \mathrm{H}$, $\mathrm{d}, J=2.3 \mathrm{~Hz}), 2.90-3.08(2 \mathrm{H}, \mathrm{m}) ;{ }^{13} \mathrm{C}$ NMR $(125 \mathrm{MHz}$, DMSO- $\left.d_{6}\right) \delta 196.9,149.3,139.4,134.1,129.4,128.0,126.7$, $124.5,123.1,65.5,64.1,53.2$; HRMS calcd for $\mathrm{C}_{14} \mathrm{H}_{14} \mathrm{O}_{4} \mathrm{~S}_{2}$ $(\mathrm{M}+\mathrm{Na})^{+} 333.0226$, found 333.0229.

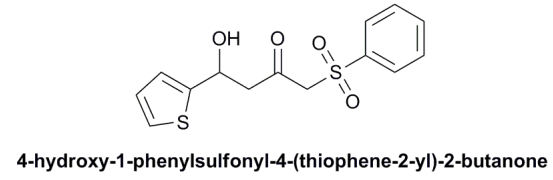

1-Diazo-4-hydroxy-1-phenylsulfonyl-4-(thiophene-2-yl)-2butanone. To a solution of 4-hydroxy-1-phenylsulfonyl-4(thiophene-2-yl)-2-butanone $(158 \mathrm{mg}, 0.51 \mathrm{mmol})$ in $15 \mathrm{~mL}$ of acetonitrile under argon at $0{ }^{\circ} \mathrm{C}$ was added successively triethylamine $(97 \mu \mathrm{L}, 0.7 \mathrm{mmol})$ and $p$-acetamido benzene sulfonyl azide ( $p$-ABSA) (123 mg, $0.51 \mathrm{mmol})$. The mixture was stirred for 2 hours and was allowed to warm to room temperature and was diluted with $50 \mathrm{~mL}$ of $\mathrm{Et}_{2} \mathrm{O} / n$-Hexane $(1: 1)$ and then filtered. The filtrate was concentrated to afford 1-Diazo-4-hydroxy-1-phenylsulfonyl-4-(thiophene-2-yl)-2butanone 1n as yellow oil. The residue was directly used for the next step without further purification due to the degradation of the diazo derivative.

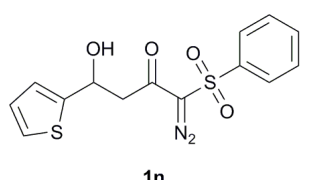

3-(Phenylsulfonyl)-6-(thiophene-2-yl)pyridazin-4-ol (2n). To a solution of $\mathbf{1 n}$ in $5 \mathrm{~mL}$ of acetonitrile under argon was added IBX (1-hydroxy-1,2-benziodoxol-3(1H)-one 1-oxide) (196 mg, $0.7 \mathrm{mmol}$ ). The mixture was refluxed for 2 hours and was allowed to cool down to room temperature and then filtered. The filtrate was concentrated and used directly without further purification for the next step.

To the previously prepared crude in $5 \mathrm{~mL}$ of toluene under argon was added 3 (9 $\mathrm{mg}, 0.05 \mathrm{mmol}$ ) followed by diphenylsilane $(103 \mu \mathrm{L}, 0.55 \mathrm{mmol})$. The reaction mixture was heated at $100{ }^{\circ} \mathrm{C}$ for 16 hours. After completion of the reaction monitored by TLC, the reaction mixture was allowed to cool to room temperature. $\mathrm{CH}_{2} \mathrm{Cl}_{2}$ was added and the organic layer was then washed 2 times with $10 \mathrm{~mL}$ of saturated aqueous $\mathrm{NaHCO}_{3}$ and 1 time with $10 \mathrm{~mL}$ of saturated aqueous $\mathrm{NaCl}$. The organic layer was dried over $\mathrm{Na}_{2} \mathrm{SO}_{4}$ and concentrated in vacuo, the residue was purified by flash column chromatography on silica gel $(\mathrm{EtOAc} / \mathrm{MeOH}=8: 2)$ to obtain the desired 3- 
(phenylsulfonyl)-6-(thiophene-2-yl)pyridazin-4-ol (2n) (67 mg, $0.21 \mathrm{mmol}, 42 \%$ yield over three steps) as pale yellow solid; mp 198-201 ${ }^{\circ} \mathrm{C}$; ${ }^{1} \mathrm{H}$ NMR (500 MHz, DMSO- $\left.d_{6}\right) \delta 8.02(2 \mathrm{H}, \mathrm{d}$, $J=7.3 \mathrm{~Hz}), 7.93(1 \mathrm{H}, \mathrm{d}, J=4.4 \mathrm{~Hz}), 7.85(1 \mathrm{H}, \mathrm{d}, J=3.7 \mathrm{~Hz})$, $7.76(1 \mathrm{H}, \mathrm{t}, J=7.4 \mathrm{~Hz}), 7.66(2 \mathrm{H}, \mathrm{t}, J=7.2 \mathrm{~Hz}), 7.27-7.30(1 \mathrm{H}$, $\mathrm{m}), 6.89(1 \mathrm{H}, \mathrm{s}) ;{ }^{13} \mathrm{C}$ NMR $\left(125 \mathrm{MHz}, \mathrm{DMSO}-d_{6}\right) \delta 151.8$, 138.7, 134.3, 131.7, 129.6, 129.2, 129.0, 128.9; HRMS calcd for $\mathrm{C}_{14} \mathrm{H}_{10} \mathrm{~N}_{2} \mathrm{O}_{3} \mathrm{~S}_{2}(\mathrm{M}+\mathrm{H})^{+}$319.0206, found 319.0211.

\section{Typical experimental procedure for the synthesis of 20}

Ethyl 2-(2-benzoylphenyl)acetate. To a solution of ethyl benzoylacetate $(191 \mu \mathrm{L}, 1.1 \mathrm{mmol})$ and 2-(trimethylsilyl)phenyl trifluoromethanesulfonate $(418 \mathrm{mg}, 1.4 \mathrm{mmol})$ in $10 \mathrm{~mL}$ of $\mathrm{CH}_{3} \mathrm{CN}$ under argon was added anhydrous Cesium fluoride (425 $\mathrm{mg}, 2.8 \mathrm{mmol}$ ) at room temperature. The reaction mixture was refluxed for $1 \mathrm{~h}$. After completion of the reaction, the reaction mixture was cooled down to room temperature, and a saturated solution of $\mathrm{NaCl}(15 \mathrm{~mL})$ was added. The phases were separated and the aqueous layer was extracted two times with $\mathrm{CH}_{2} \mathrm{Cl}_{2}(15 \mathrm{~mL})$. The combined organic layers were dried over $\mathrm{Na}_{2} \mathrm{SO}_{4}$ and filtered. The filtrate was concentrated under reduced pressure and purified by flash chromatography $($ EtOAc/ $n$-Hexane $=1: 4)$ to provide the desired derivative ethyl 2-(2-benzoylphenyl)acetate (186 $\mathrm{mg}, 0.69 \mathrm{mmol}, 63 \%$ yield) as yellow oil. Spectral and analytical data were in agreement with previous reports. ${ }^{7}$

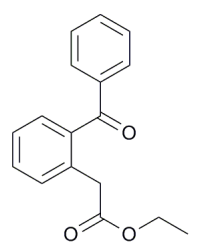

Ethyl 2-(2-benzoylphenyl)acetate

Ethyl 2-(2-benzoylphenyl)-2-diazoacetate (10). To a solution of ethyl 2-(2-benzoylphenyl)acetate $(186 \mathrm{mg}, 0.69 \mathrm{mmol})$ in 10 $\mathrm{mL}$ of $\mathrm{CH}_{3} \mathrm{CN}$ under argon at $0{ }^{\circ} \mathrm{C}$ was added $p$-acetamido benzene sulfonyl azide ( $p$-ABSA) (166 mg, $0.69 \mathrm{mmol})$ followed by 1,8-Diazabicyclo[5.4.0]undec-7-ene (DBU) (134 $\mu \mathrm{L}, 0.9 \mathrm{mmol})$. The mixture was stirred for $16 \mathrm{~h}$ and after completion of the reaction, a saturated solution of $\mathrm{NH}_{4} \mathrm{Cl}(10$ $\mathrm{mL}$ ) was added. The phases were separated and the aqueous layer was extracted two times with $\mathrm{CH}_{2} \mathrm{Cl}_{2}(10 \mathrm{~mL})$. The combined organic layers were dried over $\mathrm{Na}_{2} \mathrm{SO}_{4}$ and filtered. The filtrate was concentrated under reduced pressure and purified by flash chromatography $(\mathrm{EtOAc} / n$-Hexane $=1: 3)$ to provide the desired product ethyl 2-(2-benzoylphenyl)-2diazoacetate (1o) (115 mg, $0.39 \mathrm{mmol}, 57 \%$ yield) as yellow oil. Spectral and analytical data were in agreement with previous reports. $^{7}$

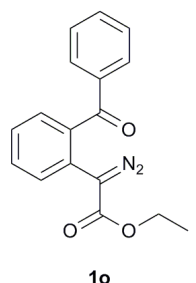

10

Ethyl 4-phenylphthalazine-1-carboxylate (2o) To a solution of $10(115 \mathrm{mg}, 0.39 \mathrm{mmol})$ in $5 \mathrm{~mL}$ of toluene under argon was added 3 ( $8 \mathrm{mg}, 0.04 \mathrm{mmol})$ followed by diphenylsilane $(80 \mu \mathrm{L}$, $0.43 \mathrm{mmol}$ ). The reaction mixture was heated at $100{ }^{\circ} \mathrm{C}$ for 16 hours. After completion of the reaction monitored by TLC, the reaction mixture was allowed to cool to room temperature and the formation of a precipitate was observed. The suspension was filtered, washed with diisopropyl ether and dried to afford the desired annulated pyridazine ethyl 4-phenylphthalazine-1carboxylate (2o) (89 mg, $0.32 \mathrm{mmol}, 83 \%$ yield) as white solid. Spectral and analytical data were in agreement with previous reports. $^{7}$

\section{Acknowledgements}

Hassen Bel Abed is indebted to the IWT (Agentschap voor Innovatie door Wetenschap en Technologie) and to Galapagos $\mathrm{NV}$ for providing a PhD-scholarship (Baekeland-project 90704). He is also grateful to Dr. Chaïma for helpful discussions.

\section{Notes and references}

${ }^{a}$ Rega Institute for Medical Research, Katholieke Universiteit Leuven, Minderbroedersstraat 10, B-3000 Leuven, Belgium.

E-mail: Piet.Herdewijn@ rega.kuleuven.be; Tel: +003216337387

${ }^{b}$ Galapagos NV, Laboratory of Medicinal Chemistry, Generaal De Wittelaan L11 A3, B-2800 Mechelen, Belgium.

Electronic Supplementary Information (ESI) available: [details of any supplementary information available should be included here]. See DOI: $10.1039 / \mathrm{b} 000000 \mathrm{x} /$

1 (a) D. L. Boger, Chem. Rev., 1986, 86, 781; (b) D. L. Boger, M. Patel, Prog. Heterocycl. Chem., 1989, 1, 30; (c) J. Sauer, In Comprehensive Heterocyclic Chemistry II, Pergamon London, 1996, 6, 901; (d) J.-J. Bourguignon, S. Oumouch, M. Schmitt, Curr. Org. Chem., 2006, 10, 277.

2 C. G. Wermuth, G. Schlewer, J.-J. Bourguignon, G. Maghioros, M.-J. Bouchet, C. Moire, J.-P. Kan, P. Worms, K. Biziere, J. Med. Chem., 1989, 32, 528.

3 N. Miyamoto, Y. Oguro, T. Takagi, H. Iwata, H. Miki, A. Hori, S. Imamura, Bioorg. Med. Chem., 2012, 20, 7051.

4 R. J. Gleave, P. J. Beswick, A. J. Brown, G. M. P. Giblin, P. Goldsmith, C. P. Haslam, W. L. Mitchell, N. H. Nicholson, L. W. Page, S. Patel, S. Roomans, B. P. Slingsby, M. E. Swarbrick, Bioorg. Med. Chem. Lett., 2010, 20, 465.

5 C. G. Wermuth, Med. Chem. Commun., 2011, 2, 935.

6 (a) X. Yang, P. Knochel, Org. Lett., 2006, 9, 1941; (b) A. Hamasaki, R. Ducray, D. L. Boger, J. Org. Chem., 2006, 71, 185; (c) O. A. Attanasi, G. Favi, P. Filippone, F. R. Perrulli, S. Santeusanio, Org. Lett., 2009, 11, 309; (d) M. D. Helm, J. E. Moore, A. Plant, J. P. A. Harrity, Angew. Chem. Int. Ed., 2005, 44, 3889; (e) M. D. Helm, A. Plant, J. P. A. Harrity, Org. Biomol. Chem., 2006, 4, 4278; (f) J. X. de Araújo-Júnior, M. Schmitt, C. Antheaume, J.-J. Bourguignon, Tetrahedron Lett., 2007, 48, 7817; (g) C. Salomé, M. Schmitt, J.-J. Bourguignon, Tetrahedron Lett., 2012, 53, 1033; (h) H. Mao, A. Lin, Z. Tang, H. Hu, C. Zhu, Y. Cheng, Chem. Eur. J., 2014, 9, 2454; (i) C. D. Mboyi, C. Duhayon, Y. Canac, R. Chauvin, Tetrahedron, 2014, DOI: 10.1016/j.tet.2014.05.005; (j) S. V. Galiullina, V. M. Zakharova, G. P. Kantin, V. A. Nikolaev, Zh. Org. Khim., 2007, 43, 
607; (k) M. B. Supurgibekov, L. Hennig, B. Schulze, V. A. Nikolaev, Zh. Org. Khim., 2008, 44, 1840; (1) M. B. Supurgibekov, N. S. Yanyuk, V. A. Nikolaev, Zh. Org. Khim., 2011, 47, 1252; (m) V. V. Zalesov, N. G. Vyaznikova, Y. S. Andreichikov, Zh. Org. Khim., 1996, 32, 705; (n) V. V. Zalesov, N. G. Vyaznikova, Y. S. Andreichikov, Zh. Org. Khim., 1996, 32, 735; (o) Z. G. Aliev, N. G. Vyaznikova, V. V. Zalesov, S. S. Kataev, Y. S. Andreichikov, L. O. Atovmyan, Russ. Chem. Bull., 1997, 46, 2142; (p) N. V. Kutkovaya, N. G. Vyaznikova, V. V. Zalesov, Zh. Org. Khim., 2003, 39, 1713; (q) N. V. Kutkovaya, N. A. Pulina, V. V. Zalesov, Zh. Org. Khim., 2004, 40, 1078.

7 (a) H. Bel Abed, O. Mammoliti, G. Van Lommen, P. Herdewijn, Tetrahedron Lett., 2013, 54, 2612; (b) H. Bel Abed, O. Mammoliti, O. Bande, G. Van Lommen, P. Herdewijn, J. Org. Chem., 2013, 78, 7845; (c) H. Bel Abed, O. Bande, O. Mammoliti, G. Van Lommen, P. Herdewijn, Tetrahedron Lett., 2013, 54, 7056.

8 H. Bel Abed, O. Mammoliti, G. Van Lommen, P. Herdewijn, Tetrahedron Lett., 2012, 53, 6489.

9 S. P. Marsden, A. E. McGonagle, B. McKeever-Abbas, Org. Lett., 2008, 10, 2589.

10 T. W. Campbell, J. J. Monagle, V. S. Foldi, J. Am. Chem. Soc., 1962, 84, 3673.

11 R. Appel, Angew. Chem., 1975, 87, 863; Angew. Chem. Int. Ed. Engl., 1975, 14, 801.

12 K. C. K. Swamy, N. N. B. Kumar, E. Balaraman, K. V. P. P. Kumar, Chem. Rev., 2009, 109, 2551.

13 (a) A. W. Johnson, in Ylides and Imines of Phosphorus, Wiley, New York, 1993; (b) N. Körber, F. Rominger, T. J. J. Müller, Synlett, 2010, 5, 782; (c) J. Panther, A. Röhrich, T. J. J. Müller, Arkivoc, 2012, 2012, 297.

14 (a) R. M. Denton, J. An, B. Adeniran, Chem. Commun., 2010, 46, 3025; (b) R. M. Denton, X. Tang, P. Przeslak, Org. Lett., 2010, 12, 4678; (c) R. M. Denton, J. An, B. Adeniran, A. J. Blake, W. Lewis, A. M. Poulton, J. Org. Chem., 2011, 16, 6749; (d) J. An, X. Tang, J. Moore, W. Lewis, R. M. Denton, Tetrahedron, 2013, 41, 8769.

15 (a) C. J. O’Brien, J. L. Tellez, Z. S. Nixon, L. J. Kang, A. L. Carter, S. R. Kunkel, K. C. Przeworski, G. A. Chass, Angew. Chem., 2009, 121, 6968; Angew. Chem. Int. Ed., 2009, 48, 6836; (b) C. J. O’Brien, F. Lavigne, E. E. Coyle, A. J. Holohan, B. J. Doonan, Chem. Eur. J., 2013, 19, 5854; (c) C. J. O’Brien, Z. S. Nixon, A. J. Holohan, S. R. Kunkel, J. L. Tellez, B. J. Doonan, E. E. Coyle, F. Lavigne, L. J. Kang, K. C. Przeworski, Chem. Eur. J., 2013, 45, 15281.

16 T. Imamoto, S. Kikuchi, T. Miura, Y. Wada, Org. Lett., 2000, 3, 87.

17 (a) H. A. van Kalkeren, A. L. Blom, F. P. J. T. Rutjes, M. A. J. Huijbregts, Green Chem., 2013, 15, 1255; (b) H. A. van Kalkeren, F. L. van Delft, F. P. J. T. Rutjes, ChemSusChem, 2013, 9, 1615; (c) D. C. Lenstra, F. P. J. T. Rutjes, J. Mecinović, Chem. Commun., 2014, 50, 5763.

18 H. A. van Kalkeren, F. L. van Delft, F. P. J. T. Rutjes, Pure Appl. Chem., 2013, 85, 817.

19 H. A. van Kalkeren, J. J. Bruins, F. P. J. T. Rutjes, F. L. van Delft, Adv. Synth. Catal., 2012, 354, 1417.

20 H. A. van Kalkeren, C. Grotenhuis, F. S. Haasjes, C. A. Hommersom, F. P. J. T. Rutjes, F. L. van Delft, Eur. J. Org. Chem., 2013, 31, 7059.

21 H. A. van Kalkeren, S. H. A. M. Leenders, C. R. A. Hommersom, F. P. J. T. Rutjes, F. L. van Delft, Chem. Eur. J., 2011, 17, 11290.
22 L. Zhou, M. P. Doyle, Org. Lett., 2010, 12, 796. 